\title{
Children are being sidelined by covid-19
}

\author{
They must not be left behind in its aftermath
}

\author{
Ian Sinha consultant ${ }^{1}$, Davara Bennett researcher ${ }^{2}$, David C Taylor-Robinson professor $^{12}$
}

'Alder Hey Children's Hospital, Liverpool, UK; ${ }^{2}$ Department of Public Health and Policy, Farr Institute@HeRC, Liverpool, UK

When the Titanic sank there was a linear relation between the social class of passengers and their risk of drowning. ${ }^{1}$ During the bubonic plague, the upper classes fled Italian cities for safer country residences, heeding the public health advice, "cito, longe, tarde" (flee early, flee far, return late) ${ }^{2}$; the less wealthy were left behind and died disproportionately as a result. A similar pattern was seen in New Orleans during Hurricane Katrina. ${ }^{3}$ History tells us that, during times of crisis, vulnerable groups lose out most. The covid-19 pandemic is no different. Emerging data show the pandemic tracking along social fault lines. ${ }^{4}$ And although children are not the face of this pandemic, they are deeply affected. The UN warns of "unprecedented risks to the rights and safety and development of the world's children." 5

During childhood, we are especially vulnerable to the main determinants of health: living conditions, family income, employment, education, access to health services. The pandemic can be conceived as an additional systemic shock to these determinants. In the shorter term, with the focus squarely on adults with covid-19, child health and social care services are being sidelined. These include acute services for life threatening illnesses, outpatient services for chronic conditions, child protection services guarding against abuse and neglect, and preventive services that support early years development, routine checks, and immunisations. Global modelling predicts a stark increase in child mortality as a result of diversion of care. ${ }^{6}$ As soon and as seamlessly as possible, we must restore these services to full, and greater, capacity. ${ }^{5}$

Within family homes, the unintended consequences of the lockdown will affect poor children the most. Greater "toxic stress" for many families will increase the risk of neglect and domestic violence. ${ }^{7}$ Exposure to these adversities can have lifelong health impacts. Many children are going hungry as foodbanks scramble to reconfigure services to meet the rising tide of food insecurity. ${ }^{8}$ Lockdown in poor quality and overcrowded housing, with inequitable access to safe green space, will disrupt children's lives, some more than others. ${ }^{9}$

Social distancing measures and school closures are interrupting educational trajectories. Teachers must be commended for developing online resources, under huge pressure and in difficult circumstances, but for some children the lack of internet, electronic devices, and quiet space at home will further exacerbate inequalities in educational outcomes. Despite plans for the phased reopening of schools, an increasing dependence on supplementary online learning seems assured.

\section{Child poverty}

In the longer term, we must consider the effects of an economic recession on child health. Covid-19 has already caused the most aggressive decline in the global economy seen in modern times. ${ }^{10}$ The 2008 financial crash taught us that, of all age groups, children are most likely to fall into poverty. ${ }^{11}$ In 2017 , child poverty, a major driver of poor child health, had risen to 4.1 million children, or $30 \%$ of all English children. ${ }^{12}$ The UN pronounced child poverty in the UK "not just a disgrace, but a social calamity and an economic disaster." ${ }^{13}$ Before the pandemic, child poverty was predicted to rise steeply in the coming years. Now we must revisit these predictions: $75 \%$ of children already in poverty belong to a family with one working parent; 6 million workers are estimated to become unemployed in the UK as a result of the pandemic; and parents working low hours contracts or within the "gig economy" are particularly vulnerable.

Swift financial action has sought to mitigate the economic effect of covid-19. But short term macroeconomic stabilisation often comes at the expense of subsequent public spending. Austerity measures affect deprived children disproportionately, and the rollout of Universal Credit was predicted to be a major driver of child poverty. ${ }^{14}$ Immediate action is needed to put money in the pockets of families with children. A modest increase in child benefit of $£ 10$ a week for each child would reduce child poverty by $5 \% \cdot{ }^{15}$ More generous universal credit payments to families with children should be a priority, and the two child limit should be scrapped. ${ }^{16}$

The furlough scheme should be extended to caregivers who must look after their children. Even as schools reopen, the Department for Education should work with local authorities and digital providers to ensure all children's access to a computer and broadband. In the longer term, funding for services that support children should be increased and delivered according to need. Research and health equity impact assessments must 
shed light on the long term unintended consequences of control measures for children and inform policy responses. ${ }^{4}$

Many of the medical problems seen in deprived children flow from restricted opportunities to be healthy-exposure to poverty, unhealthy environments, lower quality nutrition, poor quality air, substandard housing, and chronic stress. We cannot predict how this pandemic will play out, or for how long. What is certain is that, unless there is a proactive and concerted policy focus on vulnerable children, they will face the fall-out.

The UN Convention on the Rights of the Child affords children special protection. We must ensure that these rights are not overlooked, as they have been in the past. Children will get left behind unless we act now.

Competing interests: The BMJ has judged that there are no disqualifying financial ties to commercial companies. The authors declare the following other interest: DT-R is funded by the MRC on a clinician scientist fellowship (MR/P008577/1). DT-R and DB are supported by the National Institute for Health Research School for Public Health Research.

Provenance and peer review: Not commissioned; externally peer reviewed.

Hall W. Social class and survival on the S.S. Titanic. Soc Sci Med 1986;22:687-90. 10.1016/0277-9536(86)90041-9 3520835

2 Cito, longe, tarde: fly quickly, go far, return slowly. The Repository, Royal Society https:/ /blogs.royalsociety.org/history-of-science/2015/03/09/great-plague/

3 Sharkey P. Survival and death in New Orleans: an empirical look at the human impact of Katrina. J Black Stud 2007;37:482-50110.1177/0021934706296188 .

4 Whitehead M, Barr B, Taylor-Robinson D. Covid-19: we are not "all in it together"-less privileged in society are suffering the brunt of the damage. BMJ Opinion, 22 May 2020 https://blogs.bmj.com/bmj/2020/05/22/covid-19-we-are-not-all-in-it-together-less-privilegedin-society-are-suffering-the-brunt-of-the-damage/
5 United Nations. Policy brief: the impact of covid-19 on children. https://www.un.org/sites/ un2.un.org/files/policy_brief_on_covid_impact_on_children_16_april_2020.pdf

6 Roberton T, Carter ED, Chou VB, etal . Early estimates of the indirect effects of the COVID-19 pandemic on maternal and child mortality in low-income and middle-income countries: a modelling study. Lancet Glob Health 2020; [Epub ahead of print.]. 10.1016/S2214-109X(20)30229-132405459

7 Guardian view on children in the pandemic: hidden victims. Guardian 2020 Apr 28. https: //www.theguardian.com/commentisfree/2020/apr/28/the-guardian-view-on-children-in-thepandemic-hidden-victims

8 Food Foundation. Covid-19: latest impact on food. 2020. https://foodfoundation.org.uk/ covid-19-latest-impact-on-food/

9 Rosenthal DM, Ucci M, Heys M, Hayward A, Lakhanpaul M. Impacts of COVID-19 on vulnerable children in temporary accommodation in the UK. Lancet Public Health 2020;5:e241-2. 10.1016/S2468-2667(20)30080-3 32243776

10 McKee M, Stuckler $\mathrm{D}$. If the world fails to protect the economy, COVID-19 will damage health not just now but also in the future. Nat Med 2020;26:640-2. 10.1038/s41591-020-0863-y 32273610

11 Rajmil L, Fernandez de Sanmamed M-J, Choonara I, etal. International Network for Research in Inequalities in Child Health (INRICH). Impact of the 2008 economic and financial crisis on child health: a systematic review. Int $J$ Environ Res Public Health 2014;11:6528-46. 10.3390/ijerph110606528 25019121

12 Taylor-Robinson DC, Lai ET, Whitehead M, Barr B. Child health unravelling in UK. BMJ 2019;364:I963. 10.1136/bmj.I963 30837239

13 OHCHR. Statement on visit to the United Kingdom, by Professor Philip Alston, United Nations Special Rapporteur on extreme poverty and human rights. 2018. https://www. ohchr.org/en/NewsEvents/Pages/DisplayNews.aspx?NewsID=23881\&LangID=E

14 Wickham S, Bentley L, Rose T, Whitehead M, Taylor-Robinson D, Barr B. Effects on mental health of a UK welfare reform, Universal Credit: a longitudinal controlled study. Lancet Public Health 2020;5:e157-64. 10.1016/S2468-2667(20)30026-8 32113519

15 Bradshaw J, Keung A. Poor children need a coronavirus bonus. 2020.https://cpag.org. uk/sites/default/files/files/policypost/BRIEFING-Covid-19_income\%20top\%20up\%20child\% 20poverty\%20analysis.pdf

16 IPPR. Children of the pandemic. $2020 \mathrm{https}: / /$ www.ippr.org/research/publications/childrenof-the-pandemic

This article is made freely available for use in accordance with BMJ's website terms and conditions for the duration of the covid-19 pandemic or until otherwise determined by BMJ. You may use, download and print the article for any lawful, non-commercial purpose (including text and data mining) provided that all copyright notices and trade marks are retained.

https://bmj.com/coronavirus/usage 